\begin{tabular}{|c|c|}
\hline & $\begin{array}{l}\text { International Journal of Trend in Scientific } \\
\text { Research and Development (IJTSRD) }\end{array}$ \\
\hline 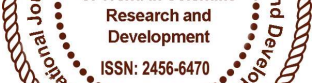 & International Open Access Journal \\
\hline 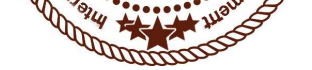 & ISSN No: 2456 - 6470 | www.ijtsrd.com | Volume - 2 | Issue - 2 \\
\hline
\end{tabular}

\title{
Relationship between Dividend Policy and Volatility of the share prices: Evidence from Indian Pharmaceutical and IT companies
}

Prasad. R

Department of Management Studies, Christ deemed to be University, Bengaluru, India
Prof. Anuradha. R

Department of Management Studies, Christ

deemed to be University, Bengaluru, India

\section{ABSTRACT}

The article aims at finding the relationship between the dividend policy and the Volatility of the share prices. Dividend Yield and Dividend Payout has been used to measure the dividend policy. Other control variables such as the Earnings Volatility, Long-Term Debts, Growth in Assets, Firm Size have been used. The data has been collected from the financial years of 2011-2017. Multiple regression and correlation test have been used to find the relationship between the dividend policy and Volatility of the share prices. The findings showed that the Earnings Volatility, Growth In Assets, Long-Term Debts are positively correlated with price volatility while Dividend Payout, Dividend Yieldand Firm Size are negatively correlated with the price volatility.

Keywords: Dividend Yield, Dividend Payout, Earnings Volatility, Long-Term Debts, Growth in Assets, Firm Size

\section{Introduction:}

The dividend policy is the most debated topic in the financial literature, many papers have been done abroad in order to understand the relationship between the dividend policy and the share prices. MM approach states that the dividend policy and the share prices do not have any relationship but the dividend policy is one of the determinants of the increase or decrease of the shareholders wealth, so when there is an increase in the shareholder wealth the investors will try to invest more thereby increasing the price of the share prices. Though this holds true in some countries, the relationship between the dividend policies on the share prices may be positive or negative.

This paper focuses on establishing a relationship between the dividend policy and the Volatility of the share prices in Indian pharmaceutical sector and the IT sector. The recent changes in the stock market show how the trading is done on the speculative basis. Though, it is by the speculative motive the prices are changing in the upward or downward moment. The new investors will have to know the main idea of how this change will occur. The investor will be better off if he knows when the price of the stock will be down in order to buy the stock at low prices. Similarly, the relationship between the dividend policy and the share prices will help the company managers to take proper decision in order to control the volatility of the stocks. Many research studies have been carried out in many developed and developing countries, but the relationship between dividend policy (Dividend Payout, Dividend Yield) and stock price volatility is not clear. This article aims at providing clarity in the relationship between the dividend policy(Dividend Payout, Dividend Yield) and the Volatility of the share prices. The study uses the control variables such as the Earnings Volatility, Long-Term Debts, and Growth in Assets, Firm Size to make the model free from the effect of these variables. 


\section{Statement of problem:}

The relationship between the dividend policy (Dividend Yield and Dividend Payout) and the Volatility of the share prices has been analyzed to have a positive relationship in the developed countries and found to have a negative relationship in dynamic countries. The study aims to prove whether the statement holds true for our dynamic Indian economy.

\section{Objectives:}

- To understand the relationship between the Dividend Payout and the Dividend Yield with volatility of the stock prices.

- To analyze the impact of the growth of assets and the Firm Size on the Volatility of the share prices.

- To analyze the impact of the long-term debt and Earnings Volatility on the Volatility of the share prices

\section{Research hypothesis:}

$\mathbf{H}_{\mathbf{1}}$ : Dividend Yield ratio and Volatility of the share prices is positively related

$\mathbf{H}_{2}$ : Dividend Payout ratio and Volatility of the share prices is positively related

$\mathbf{H}_{3}$ :Earnings Volatility and Volatility of the share prices is positively related

$\mathbf{H}_{4}$ :Long-Term Debts and Volatility of the share prices is positively related

H5: Growth In Assets and Volatility of the share prices is positively related

$\mathbf{H}_{6}$ : Firm Size and Volatility of the share prices is positively related

\section{Review of literature:}

Nawaz et al (2010) undertook an analysis on the relationship between the stock prices and the corporate dividend policy. The study showed there is a significant positive relationship between the dividend policy and the stock prices volatility. Fixed effect and random effect data have been followed in the data. The study showed that the Dividend Yield has been having a significant relationship on the Volatility of the share prices.

Azzam (2010) undertook a study on the institutional ownership and the dividend policy and the Volatility of the share prices in Egypt. The study showed that the privateinstitutional ownership has a negative effect on Dividend Payout ratio. The study also shows that private institutional ownership significantly increases volatility for non-dividend paying stocks only because these stocks are more subject to institutional herding than dividend paying stocks.

Hussainey and Mgbane (2011) undertook a study on the prices of share and the dividend policy in the UK stock market. The study shows that the Dividend Yield ratio has a positive relationship with the Volatility of the share prices. It shows that there is negative relationship with the Dividend Payout ratio.

Malhotra and Tandon (2013) undertook a study on the determinants of the stock prices with the NSE listed 100 companies. The study shows that the Book value, EPS, P/E ratio has a significant influence on the firm share prices. It also showed that there is a Dividend Yield has an inverse relationship with the market price of the share.

Alayemi and Adebayo (2013) undertook a study on the profitability and the share prices in the Nigerian stock market. The study showed that there is a statistically significant relationship between the dividend paid and the changes in the stock prices. It showed that there is a negative correlation between the profitability of the company and the stock prices in Nigerian stock market.

Masum (2014) studied that there are a lot of factors that have an impact on the share prices. The study showed that there is always changes in the effect of the share prices by the dividend policy and it may be positively or negatively related. The study showed that the variables like the EPS, ROE and retention ratio has a positive relationship with the stock prices while the variable like the Dividend Yield and the profit after tax has a negative relationship between the stock prices.

Rashid and Rahman (2014) undertook a study on the relationship between the dividend policy and the share prices in Bangladesh. The study showed that there is no positive relationship between the Dividend Yield and the share prices. The study also showed that there is no significant impact of the dividend announcements and the share prices.

Velnampy et al. (2014) studied that there is a inverse relationship between the Dividend policy (Dividend Payout and theDividend Yield ratio) and theperformance of thefirm. The research used the Return on Asset ratio and the Return on Equity ratio as the determinant of the performance of the firm. The study showed that there is no effect of the dividend 
policy on the firm value supporting the MM's theory of dividend policy.

Gharaibeh (2015) studied the various factors that may affect the stock prices using the various statistical methods. It showed that the one year -lagged price of the stock, inflation rate, tangibility of assets, economic progress proxies by per - capita gross domestic product, money supply, change in growth opportunities, profitability and liquidity of the firm have a positive relationship with the share prices. The variable like the dividend policy, Firm Sizeand theexchange rate has apositive but statistically insignificant relationship with the share prices.

Shah and Noreen (2016) undertook a study on the Volatility of the share prices and the dividend policy in the Pakistan stock market. The study showed that there is a statistically significant direct relationship between the Dividend Yield ratio and the Dividend Payout ratio with the Volatility of the share prices. The study also found that there is an inverse relationship between the Firm Size and the long-term debt with the Volatility of the share prices.

\section{Methodology:}

The study uses the historical data for finding the relationship of the dividend policy on the Volatility of the share prices. The study has taken the companies in the NIFTY PHARMA and Nine companies in the NIFTY IT to understand the relationship in a deep level of both the industries. There are two sources of data: primary and secondary; however, the study uses the secondary data as the data is historical in nature. The data has been taken from the financial statements of the ten companies from the company website and the NSE website for the closing prices of the stocks. The data for the research has been conducted for a period of seven years (from financial year 2011 to 2017). The share prices for the computation of the price volatility have been taken from $1^{\text {st }}$ April 2011 to $31^{\text {st }}$ March 2017 to avoid the change in the results. Multiple Regression and correlation have been used for this study. The regression equation is as follows:

$\mathrm{PV}=\mathrm{A}_{1}+\mathrm{A}_{2} \mathrm{DY}+\mathrm{A}_{3} \mathrm{DP}+\mathrm{A}_{4} \mathrm{EV}+\mathrm{A}_{5} \mathrm{LTD}+\mathrm{A}_{6}$ $\mathrm{GIA}+\mathrm{A}_{7} \mathrm{FS}+\mathrm{e}$
Data analysis and interpretation:

Table 1 represents the descriptive statistics

Descriptive Statistics
\begin{tabular}{|l|l|l|l|}
\hline & Mean & Std. Deviation & N \\
\hline PV & .485161 & .2938318 & 133 \\
DY & .014870 & .0195278 & 133 \\
DP & 306571 & .5861213 & 133 \\
EV & .776417 & .3645052 & 133 \\
LTD & .076601 & .1142165 & 133 \\
GIA & .231144 & .4353008 & 133 \\
FS & 26.181008 & 1.7834869 & 133 \\
\hline
\end{tabular}

Table 1 shows the descriptive statistics of price volatility (PV), Dividend Yield (DY),Dividend Payout (DV), Earnings Volatility (EV), Long-Term Debts (LTD), Growth In Assets (GIA) and Firm Size (FS). The price volatility (PV), Dividend Yield (DY),Dividend Payout (DV), Earnings Volatility (EV), Long-Term Debts (LTD), Growth In Assets (GIA)has the standard deviation of 0.2938318 , $0.0195278,0.5861213,0.3645052,0.1142165$, 0.4353008 , respectively indicating that the data of these variables are distributed around the mean. The standard deviation for Firm Size is at 1.78 showing that the data of the Firm Size is widely distributed.

Table 2 shows the correlation values of price volatility (PV), Dividend Yield (DY), Dividend Payout (DV), Earnings Volatility (EV), Long-Term Debts (LTD), Growth In Assets (GIA) and Firm Size (FS). There is an inverse relationship between the price volatility and the Dividend Yield at 0.004 and with Dividend Payout at 0.101. Earnings Volatility, Long-Term Debts, and Growth in Assets are positively related to the Volatility of the share prices. The Growth In Asset has a less correlation with the price volatility at 0.05 . The Earnings Volatility has the highest positive correlation with price volatility at 0.181 . There is a negative relationship between the Firm Size and the price volatility at -0.204 .

Table 3 shows the coefficient value. From the standardised beta value of Dividend Yield (DY), Dividend Payout (DV), Earnings Volatility (EV), Long-Term Debts (LTD), Growth In Assets (GIA) and Firm Size (FS) will show the level in which each variable will have an impact on the dependent variable that is on the price volatility (PV).The Earnings Volatilityhas the highest impact on the price volatility at 0.210 with the p-value at 0.017 
(significant). The Dividend Yield has a high impact on the price volatility at 0.184 with the p-value at 0.126 (insignificant). The long-term debt has the impact at 0.162 at a p-value of 0.055 (significant) followed by Growth in Assets at 0.045 at a p-value of 0.610 (insignificant). The Dividend Payout has a high negative impact on the price volatility at -0.223 at a p- value of 0.071 (insignificant). The Firm Size has a negative impact on the price volatility at -0.173 with a p-value of 0.042 (insignificant). The ANOVA result is at 0.009 (below 0.05) showing the model to be significant.

The unstandardized beta helps in formulating the regression equation. The multiple regression equation is:

Price volatility $(\mathrm{PV})=1.054+2.774$ Dividend Yield $(\mathrm{DY})-0.112$ Dividend Payout $(\mathrm{DP})+0.170$ Earnings Volatility(EV) +0.417Long-Term Debts (LTD) +0.031Growth In Assets (GIA) -0.029Firm Size (FS)

Table 2 represents the correlation values

\begin{tabular}{|c|c|c|c|c|c|c|c|c|}
\hline \multicolumn{9}{|c|}{ Correlations } \\
\hline & & $\mathrm{PV}$ & DY & DP & EV & LTD & GIA & FS \\
\hline \multirow{7}{*}{$\begin{array}{l}\text { Pearson } \\
\text { Correlation }\end{array}$} & PV & 1.000 & -.004 & -.101 & .181 & .165 & .050 & -.204 \\
\hline & DY & -.004 & 1.000 & .708 & -.025 & -.072 & -.118 & .044 \\
\hline & DP & -.101 & .708 & 1.000 & .110 & -.063 & -.252 & .056 \\
\hline & EV & .181 & -.025 & .110 & 1.000 & -.029 & -.228 & -.087 \\
\hline & LTD & .165 & -.072 & -.063 & -.029 & 1.000 & .043 & -.034 \\
\hline & GIA & .050 & -.118 & -.252 & -.228 & .043 & 1.000 & -.063 \\
\hline & FS & -.204 & .044 & .056 & -.087 & -.034 & -.063 & 1.000 \\
\hline
\end{tabular}

Table 3 represents the coefficients value

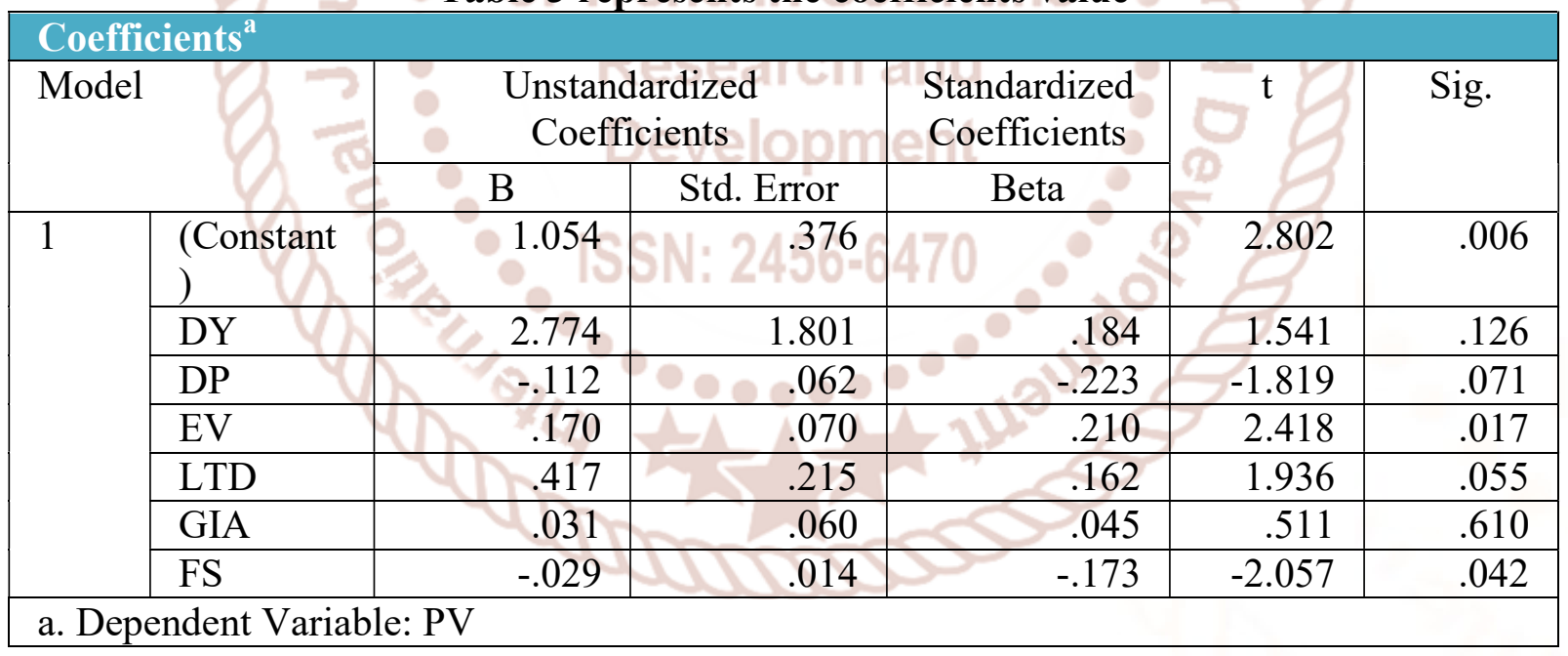

\section{Hypothesis testing:}

The correlation analysis provides that there is a positive relation between the Volatility of the share prices and the Earnings Volatility, Growth in Assets, Long-Term Debts. The analysis also found negative relationship between Share price Volatility and the Dividend Yield, Dividend Payout, Firm Size. Hence $\mathrm{H}_{3}, \mathrm{H}_{4}$, and $\mathrm{H}_{5}$ are accepted. $\mathrm{H}_{1}, \mathrm{H}_{2}$, and $\mathrm{H}_{6}$ are rejected.

\section{Findings:}

The research studies the relationship between the dividend policy and the Volatility of the share prices in the Indian pharmaceutical industry and the Information technology. The study shows that there is an inverse relation between the Dividend Policy (Dividend Yield and Dividend Payout) and the Volatility of the share prices. The main reason is attributed to the fact that the investors are more concerned on the dividend they will receive. When the payout ratio increases the investors will receive more dividends. Also, when there is increase in the 
dividend in relation to the market price, it sends a signal that the company is willing to get more profit in the future in relation to the current market price. There by it will reduce the risk associated with a particular stock. This can also be interpreted that the stocks of the pharmaceutical industry and the Information Technology industry are defensive in nature. The study also shows that there is negative relationship between the Firm Size and the Volatility of the share prices. The investors will perceive that an increase in the Firm Size will improve the competitiveness of the firm, that is there is a direct relationship between the Firm Size and competitiveness of the company. Since the revenue of these two industries depend on the research and development, which assumes more competition for the company to invent new marketable product. The Earnings Volatility is directly related to the price volatility, when the earnings fluctuates more it means the company has to incur some expenses which will reduce the dividends for the shareholders. The Growth in Assets and the long term debts are also positively related to the price volatility. The main reason is that when these variables increases the company will have to part with the earnings like depreciation, interest etc., that will not produce any return for the company. It also signals that the company is not able to have a control on these variables which has a large influence on the profit of the company.

\section{Suggestion and limitation:}

The study has been done for a limited period of time and it does not include the effect on the relationship caused by the recent implementation of the GST. Further study can be undertaken using more industries and with more number of years. Studies can also be taken on industries whose revenue depends on the innovative products.

\section{Conclusion:}

The study has established the relationship between the dividend policy and the Volatility of the share prices. The research shows that there is a significant positive relationship between the Long-Term Debts and the Volatility of the share prices. It also shows that there is an insignificant but positive relationship between the Growth in Assets, Earnings Volatility and the Volatility of the share prices. The study shows that there is an insignificant negative relationship between the dividend policy (Dividend Yield and Dividend Payout), Firm Size and Volatility of the share prices.

\section{References:}

1. Alayemi.,Adebayo.S.,(2013) relationship between Dividend Payout ratio and market price of the share Indian journal of commerce and management studies.

2. Azzam.I., (2010) The Impact of Institutional Ownership and Dividend Policy on Stock Returns and Volatility: Evidence from Egypt international journal of business.

3. Ghabraibeh.A.,(2015)the determinants of common stock prices: new empherical evidences from Kuwait. International journal of economics and business review.

4. Hussainey.A ,, Mgbane.C., (2011) Dividend policy and Volatility of the share prices: UK evidence. The Journal of risk finance.

5. Malhotra.N., Tandon.K.,(2013) determinants of stock prices: empherical evidence from NSE 100 companies. International Journal of research in management and technology.

6. Masum.A.,(2014) dividend policy and its impact on stock prices- a study of impact on commercial banks listed in Dhaka stock exchange.Global disclosure of Economics and business.

7. Nazir.M.,Nawaz.M.,Anwar.W.,Ahmed.F.(2010) determinants of stock price volatility in Karachi Stock exchange: the mediating role of corporate dividend policy. International research journal of finance and economics.

8. Rashid.A.,Rahman.A., (2014) Dividend Policy and Stock Price Volatility: Evidence from Bangladesh. Journal of Applied business and economics

9. Shah.N.,Noreen.U., (2016) Stock Price Volatility and Role of Dividend Policy: Empirical Evidence from Pakistan. International journal of finance and economic issue. The journal of risk finance

10. Velnampy.T., Nimalthasan.V.,Kalaiarasi.P.,(2014) dividend policy and firm performance: evidence from the manufacturing companies listed in Colombo stock exchange.Journal of management and research. 